\title{
Proteomic Characterization of Specific Minor Proteins in the Human Milk Casein Fraction
}

\author{
Yalin Liao, ${ }^{+,}$Rudy Alvarado, ${ }^{\neq, \S}$ Brett Phinney, ${ }^{\ddagger}$ and Bo Lönnerdal ${ }^{*,+}$ \\ ${ }^{\dagger}$ Department of Nutrition, ${ }^{\ddagger}$ Genome Center Proteomics Core Facility, University of California, One Shields Avenue, Davis, California \\ 95616, United States
}

Supporting Information

ABSTRACT: Human milk contains many bioactive proteins that are likely to support the early development of the newborn. The aim of this study was to identify whether there are specific minor proteins associated with the human milk casein micelle prepared by the acid precipitation method. Protein identification was performed by liquid chromatography tandem mass spectrometry analysis. Eighty-two proteins were identified in the casein micelle, 18 of which are not present in their whey compartment. Thirty-two of these proteins specifically associated with the casein micelle have not previously been identified in human milk or colostrum. Proteins involved in immune function comprised the major part (28\%) of total proteins, and another significant part is involved in metabolism/energy production (22\%). Most of the proteins were of extracellular or cytoplasmic origin

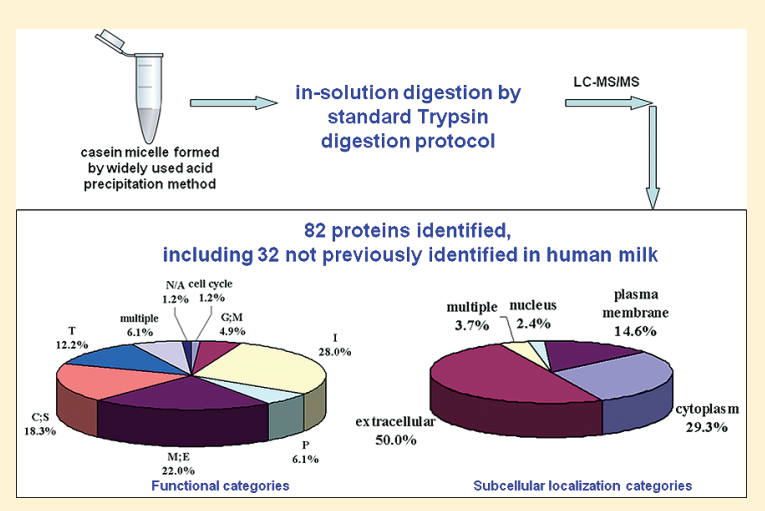
(accounting for 50 and 29\%, respectively). This study indicates that various soluble proteins should be considered as part of the casein compartment, prepared by the acid precipitation method. The data provide new insight not only into the proteomic profile of the human milk casein micelle and its physiological significance, but also into the proper proportion of casein and casein-associated proteins to use in infant formula.

KEYWORDS: human milk, casein, protein, proteomics, LC-MS/MS

\section{INTRODUCTION}

Human milk contains proteins and peptides that provide valuable biological functions in the newborn. These proteins are present in three compartments: the aqueous whey fraction containing the majority of soluble milk proteins, the casein micelle consisting predominantly of casein proteins, and only $4-5 \%$ in the milk fat globule membrane (MFGM) fraction. ${ }^{1-3}$ Most bioactive human milk proteins described to date have been found in the whey fraction; aside from the $\beta$-casein and $\kappa$-casein subunits, the human casein micelle has received little attention with regard to bioactivities.

Casein micelles are supramolecules consisting of multiple molecular entities organized by noncovalent intermolecular bonds. ${ }^{4}$ Casein constitutes approximately $20 \%$ of the total protein content of human milk during early lactation and $\sim 45 \%$ during late lactation, ${ }^{5}$ whereas an average of $80 \%$ of total protein in bovine milk $^{6}$ and $\sim 70 \%$ of total protein in sheep milk ${ }^{7}$ is casein. The human casein fraction is a major source of calcium and phosphate for the newborn infants. Several biological activities have also been demonstrated for the major casein subunits in human milk, i.e., $\beta$ - and $\kappa$-casein. $\beta$-Casein is a highly phosphorylated protein, and the closely spaced phosphoserine and phosphothreonine residues have been shown to chelate calcium and facilitate its absorption. ${ }^{8,9}$ Various proteolytic fragments of $\beta$-casein have been shown to have opioid activities, which may have physiological effects on behavior, such as sleep/ wake cycles. ${ }^{10}$ Human $\kappa$-casein is a heavily glycosylated protein and has been shown to inhibit the adhesion of Helicobacter pylori to human gastric mucosa. ${ }^{11}$ Proteolytic digestion of $\kappa$-casein results in formation of a large carbohydrate-containing moiety, glycomacropeptide, which has been shown to have immuneenhancing effects. ${ }^{12}$ There is further evidence for beneficial effects of the milk casein fraction in children. In a randomized 7 day supplementation study in prepubertal Caucasian boys, milk whey and casein fractions exhibited distinctly different growthpromoting effects by increasing fasting insulin or IGF-1 levels, respectively. ${ }^{13}$ Proline-rich peptides ${ }^{14,15}$ and c12 peptides $^{16}$ with angiotensin-converting enzyme inhibitory and antihypertensive activities have been isolated from casein fractions. In addition, commercial casein hydrolysates have been found to activate the innate immune system. ${ }^{17}$

It is generally accepted that the milk casein fraction contains predominantly casein proteins and calcium phosphate. ${ }^{4}$ However, interactions between whey and casein proteins occur readily. In a study using diffusing wave spectroscopy (DWS), Alexander and Dalgleish found the presence of whey protein/ kappa-casein aggregates, indicating a direct interaction between casein micelles and soluble whey protein complexes. They

Received: July 13, 2011

Published: November 15, 2011 
further confirmed that the effect was specific to the presence of casein micelles and could not arise simply from the aggregation of the whey proteins themselves. ${ }^{18}$

The objective of this study was to identify minor proteins in the human milk casein fraction prepared by the acid precipitation method.

\section{MATERIALS AND METHODS}

\section{Milk Sample Collection}

The study procedure was approved by the Institutional Review Board (IRB) at University of California Davis. Colostrum and milk samples from 1, 2, 3, 6, and 12 months of lactation were collected from 30 healthy donors. Milk was collected from one breast (at least $2-4 \mathrm{~h}$ after prior nursing) by manual expression (colostrum) or manual breast pump into $50 \mathrm{~mL}$ polypropylene containers. The complete breast was emptied and an aliquot was frozen. Mothers who delivered singleton term infants (gestational age 38-42 wks) were recruited, and mothers with maternal illnesses, such as cold, mastitis, and flu, were excluded. Samples from five women were collected at each time point. Colostrum was collected within $48 \mathrm{~h}$ of initiation of lactation. ${ }^{19}$ All women were exclusively breast-feeding up to 6 months, and partially up to 12 months of lactation. All samples were immediately stored at $-20{ }^{\circ} \mathrm{C}$ until further analyses.

\section{Protein Extraction}

Milk samples $(5 \mathrm{~mL})$ were thawed at $4{ }^{\circ} \mathrm{C}$ overnight. $\mathrm{CaCl}_{2}$ was added to a final calcium concentration of $60 \mathrm{mM}$. The $\mathrm{pH}$ was adjusted to 4.6, and samples were incubated at room temperature for $1 \mathrm{~h}^{20}$ The samples were then subjected to centrifugation at $13000 \mathrm{~g}$ for $30 \mathrm{~min}$ twice. The top cream layer and the infranatant were removed, and the precipitates were collected as the casein fraction.

The casein pellet was washed with $\mathrm{pH}$ 4.6 PBS three times, then dissolved using minimal amounts of $1 \mathrm{~N} \mathrm{NaOH}$ with protease inhibitors (Complete mini EDTA-free, Roche, Basel, Switzerland) added. The solution was centrifuged at $8500 \mathrm{~g}$ for $30 \mathrm{~min}$, dried, and stored at $-20{ }^{\circ} \mathrm{C}$ until being reconstituted with $\mathrm{pH} 7.0$ PBS buffer at $37^{\circ} \mathrm{C}$. The final concentration of casein protein was measured by the Microplate BCA protein assay kit (Pierce, Rockford, IL).

\section{In-Solution Digestion}

Proteins were digested in-solution using a standard Trypsin digestion protocol. Briefly, the proteins were dried in a vacuum centrifuge and then resuspended in $50 \mathrm{mM}$ ammonium bicarbonate. The proteins were then reduced with tris(2-carboxyethyl)phosphine (TCEP) (Pierce, Rockford, IL), alkylated by iodoacetamide, and treated with trypsin (modified trypsin, sequencing grade: Promega, Madison, WI) at a 1:50 enzyme to substrate ratio $(\mathrm{w} / \mathrm{w})$ overnight at $37^{\circ} \mathrm{C}$. The trypsin digested samples were dried and redissolved in $2 \%$ ACN/0.1\% TFA for MS analysis.

\section{LC-MS/MS}

A Paradigm MG4 HPLC system (Michrom Bio Resources, Inc., Auburn, CA) coupled with a Thermo Finnigan LTQ ion trap mass spectrometer (Thermo Scientific, Waltham, MA) through a Michrom Advance Captivespray source was used for protein separation and analysis. Fifteen micrograms of each digested sample were loaded onto a trap column (Zorbax 300SB-C18, $5 \mu \mathrm{m}, 0.3 \mathrm{~mm} \times 5 \mathrm{~mm}$ : Agilent Technologies
Inc., Folsom, CA) and desalted online. Peptides were then eluted from the trap and separated with a reverse-phase Michrom Magic C18AQ $(200 \mu \mathrm{m} \times 150 \mathrm{~mm})$ capillary column (Michrom Bioresources, Inc., Auburn, CA) at a flow rate of $2 \mu \mathrm{L} / \mathrm{min}$. Peptides were eluted using a 90 min gradient of $2 \%$ B to $35 \%$ B over $60 \mathrm{~min}, 35 \%$ B to $80 \%$ B for $15 \mathrm{~min}$, held at $80 \%$ B for $1 \mathrm{~min}$, $80 \% \mathrm{~B}$ to $5 \% \mathrm{~B}$ in $1 \mathrm{~min}$, and re-equilibrated for $13 \mathrm{~min}$ at $5 \% \mathrm{~B}$ ( $\mathrm{A}=0.1 \%$ formic acid, $\mathrm{B}=100 \%$ acetonitrile $)$ and directly sprayed into the mass spectrometer. The mass spectrometer was operated using a standard top 10 method, where one survey scan was followed by $10 \mathrm{MS} / \mathrm{MS}$ scans of the most intense ions eluting from the column. Dynamic exclusion was enabled.

\section{Data Analysis}

Database Searching. Tandem mass spectra were extracted by BioWorks version 3.3. Charge state deconvolution and deisotoping were not performed. All MS/MS samples were analyzed using X! Tandem (www.thegpm.org; version TORNADO (2010.01.01.4)). X! Tandem was set up to search the Uniprot human complete proteome set database (2010_07, 21525 entries) and 110 nonhuman common laboratory contaminants from the common repository of adventitous proteins database (www.thegpm.org), plus an equal number of reverse sequences assuming the digestion enzyme trypsin. X! Tandem was searched with a fragment ion mass tolerance of $0.40 \mathrm{Da}$ and a parent ion tolerance of $1.8 \mathrm{Da}$. Iodoacetamide derivative of cysteine was specified in X! Tandem as a fixed modification. Deamidation of asparagine and glutamine, oxidation of methionine and tryptophan, sulphone of methionine, tryptophan oxidation to formylkynurenin of tryptophan, and acetylation of the $\mathrm{N}$-terminus were specified in $\mathrm{X}$ ! Tandem as variable modifications.

Criteria for Protein Identification. Scaffold (version Scaffold_3_00_03, Proteome Software Inc., Portland, OR) was used to validate $\mathrm{MS} / \mathrm{MS}$-based peptide and protein identifications. Peptide identifications were accepted if they could be established at greater than $90.0 \%$ probability as specified by the Peptide Prophet algorithm. ${ }^{21}$ Protein identifications were accepted if they could be established at greater than $95.0 \%$ probability and contained at least two identified peptides. Protein probabilities were assigned by the Protein Prophet algorithm. ${ }^{22}$ Proteins that contained similar peptides and could not be differentiated on the basis of MS/MS analysis alone were grouped to satisfy the principles of parsimony. Using these Scaffold criteria, a false discovery rate was calculated as $0.4 \%$ on the peptide level and $4.5 \%$ on the protein level using decoy/target as discussed in ref 23 .

Assignment of Protein Function and Subcellular Localization. All the identifed proteins were analyzed in the Human Protein Reference Database (http://www.hprd.org/) and UniProt Database release 15.14 (http://www.uniprot.org/), to obtain functional assignment and subcellular localization according to previously published evidence.

\section{Proteomics Data Set}

The data associated with this manuscript may be downloaded from ProteomeCommons.org Tranche using the following hash: yuwIOhIRIjzPHypjlUYYqWHk4HU1RtNAImjGYMwuYe0ch Mf7YMl9ZagFTkGzGZ55hqFWkl4bZEbXeXC8liHh90WmZ WMAAAAAAAAZpA==. 
Table 1. Proteins Identified in Acid-Precipitated Human Milk Casein ${ }^{a}$

\begin{tabular}{|c|c|c|c|c|c|}
\hline $\begin{array}{c}\text { serial } \\
\text { number }\end{array}$ & protein name & accession number & $\begin{array}{c}\text { MW } \\
(\mathrm{kDa})\end{array}$ & $\begin{array}{c}\text { number of unique } \\
\text { peptides }\end{array}$ & $\begin{array}{c}\text { sequence } \\
\text { coverage (\%) }\end{array}$ \\
\hline 1 & $14-3-3$ protein zeta/delta & P63104 & 28 & 3 & 14 \\
\hline 2 & actin, cytoplasmic 1 & P60709 & 42 & 9 & 36 \\
\hline 3 & alcohol dehydrogenase & P14550 & 37 & 3 & 12 \\
\hline 4 & alpha-1-antichymotrypsin & P01011 & 48 & 7 & 25 \\
\hline 5 & alpha-1-antitrypsin & P01009 & 47 & 4 & 14 \\
\hline $6^{b}$ & alpha-2-macroglobulin-like protein 1 & A8K2U0 & 161 & 2 & 4.3 \\
\hline 7 & alpha-amylase 1 & P04745 & 58 & 2 & 7.4 \\
\hline 8 & alpha-enolase & P06733 & 47 & 4 & 15 \\
\hline 9 & alpha-lactalbumin & P00709 & 16 & 15 & 52 \\
\hline 10 & alpha-S1-casein & P47710 & 22 & 16 & 79 \\
\hline 11 & apolipoprotein A-I & P02647 & 31 & 4 & 22 \\
\hline 12 & apolipoprotein $\mathrm{D}$ & P05090 & 21 & 2 & 14 \\
\hline $13^{b}$ & ATP-binding cassette subfamily G member 2 & Q9UNQ0 & 72 & 3 & 6.4 \\
\hline 14 & beta-1,4-galactosyltransferase 1 & P15291 & 44 & 5 & 20 \\
\hline 15 & beta-2-microglobulin & P61769 & 14 & 3 & 35 \\
\hline 16 & beta-actin-like protein 2 & Q562R1 & 42 & 2 & 12 \\
\hline 17 & beta-casein & P05814 & 25 & 44 & 83 \\
\hline 18 & bile salt-activated lipase, carboxyl easter lipase & P19835 & 79 & 23 & 34 \\
\hline 19 & butyrophilin subfamily 1 member $\mathrm{A} 1$ & Q13410 & 59 & 24 & 41 \\
\hline 20 & carbonic anhydrase 6 & $\mathrm{P} 23280$ & 35 & 5 & 30 \\
\hline 21 & chitinase-3-like protein 1 & P36222 & 43 & 2 & 7.3 \\
\hline $22^{b}$ & chloride intracellular channel protein 1 & O00299 & 27 & 2 & 12 \\
\hline 23 & chordin-like protein 2 & Q6WN34 & 47 & 10 & 33 \\
\hline 24 & clusterin & P10909 & 52 & 15 & 31 \\
\hline 25 & complement C3 & P01024 & 187 & 13 & 14 \\
\hline 26 & complement $\mathrm{C} 4-\mathrm{B}$ & P0C0L5 & 193 & 19 & 15 \\
\hline $27^{b}$ & cytosolic nonspecific dipeptidase & Q96KP4 & 53 & 2 & 4 \\
\hline $28^{b}$ & endoplasmin & P14625 & 92 & 2 & 3.1 \\
\hline 29 & fatty acid synthase & P49327 & 273 & 41 & 24 \\
\hline 30 & fatty acid-binding protein, heart & P05413 & 15 & 8 & 57 \\
\hline 31 & galectin-3-binding protein & Q08380 & 65 & 4 & 12 \\
\hline $32^{b}$ & glutathione peroxidase 3 & P22352 & 26 & 2 & 13 \\
\hline 33 & glyceraldehyde-3-phosphate dehydrogenase & P04406 & 36 & 3 & 13 \\
\hline 34 & golgi-associated plant pathogenesis-related protein 1 & Q9H4G4 & 17 & 2 & 17 \\
\hline $35^{b}$ & guanine nucleotide-binding protein $\mathrm{G}(\mathrm{I}) / \mathrm{G}(\mathrm{S}) / \mathrm{G}(\mathrm{T})$ subunit beta-1 & P62873 & 37 & 2 & 5.3 \\
\hline 36 & haptoglobin & P00738 & 45 & 2 & 9.1 \\
\hline $37^{b}$ & heat shock protein beta-1 & P04792 & 23 & 2 & 13 \\
\hline $38^{b}$ & heat shock protein HSP 90-alpha & P07900 & 85 & 3 & 4.4 \\
\hline 39 & Ig alpha-1 chain $\mathrm{C}$ region & P01876 & 38 & 15 & 59 \\
\hline 40 & Ig alpha-2 chain $\mathrm{C}$ region & P01877 & 37 & 2 & 29 \\
\hline 41 & Ig gamma-1 chain $\mathrm{C}$ region & P01857 & 36 & 2 & 10 \\
\hline 42 & Ig kappa chain $\mathrm{C}$ region & P01834 & 12 & 8 & 89 \\
\hline 43 & Ig kappa chain V-III region SIE & P01620 & 12 & 2 & 38 \\
\hline 44 & Ig lambda-2 chain $\mathrm{C}$ regions & P0CG05 & 11 & 6 & 86 \\
\hline 45 & Ig lambda-7 chain $\mathrm{C}$ region & A0M8Q6 & 11 & 2 & 48 \\
\hline 46 & Ig mu chain $\mathrm{C}$ region & P01871 & 49 & 5 & 18 \\
\hline 47 & immunoglobulin $\mathrm{J}$ chain & P01591 & 18 & 4 & 26 \\
\hline 48 & kappa-casein & P07498 & 20 & 16 & 55 \\
\hline 49 & lactadherin & Q08431 & 43 & 17 & 57 \\
\hline 50 & lactoferrin & P02788 & 78 & 86 & 82 \\
\hline 51 & leucine-rich alpha-2-glycoprotein & P02750 & 38 & 2 & 13 \\
\hline $52^{b}$ & leucine-rich repeat-containing protein $16 \mathrm{C}$ & Q6F5E8 & 155 & 2 & 2.2 \\
\hline 53 & lipoprotein lipase & P06858 & 53 & 5 & 20 \\
\hline
\end{tabular}


Table 1. Continued

\begin{tabular}{|c|c|c|c|c|c|}
\hline $\begin{array}{c}\text { serial } \\
\text { number }\end{array}$ & protein name & accession number & $\begin{array}{c}\text { MW } \\
(\mathrm{kDa})\end{array}$ & $\begin{array}{c}\text { number of unique } \\
\text { peptides }\end{array}$ & $\begin{array}{c}\text { sequence } \\
\text { coverage (\%) }\end{array}$ \\
\hline 54 & lysozyme C & P61626 & 17 & 2 & 27 \\
\hline 55 & macrophage mannose receptor 1 & P22897 & 166 & 4 & 5.1 \\
\hline $56^{b}$ & malate dehydrogenase, cytoplasmic & P40925 & 36 & 2 & 8.7 \\
\hline 57 & monocyte differentiation antigen CD14 & P08571 & 40 & 5 & 29 \\
\hline 58 & mucin-1 & P15941 & 122 & 2 & 2 \\
\hline 59 & mucin-4 & Q99102 & 232 & 4 & 3.1 \\
\hline 60 & osteopontin & P10451 & 35 & 3 & 12 \\
\hline 61 & peptidyl-prolyl cis-trans isomerase A & P62937 & 18 & 3 & 27 \\
\hline 62 & perilipin-2 & Q99541 & 48 & 30 & 76 \\
\hline 63 & perilipin-3 & O60664 & 47 & 9 & 40 \\
\hline $64^{b}$ & platelet glycoprotein 4 & P16671 & 53 & 3 & 9.1 \\
\hline 65 & polymeric immunoglobulin receptor & P01833 & 83 & 22 & 39 \\
\hline 66 & prolactin-inducible protein & P12273 & 17 & 2 & 15 \\
\hline 67 & protein disulfide-isomerase & P07237 & 57 & 2 & 3.9 \\
\hline $68^{b}$ & protein QN1 homologue & Q5TB80 & 162 & 2 & 2.8 \\
\hline 69 & rab GDP dissociation inhibitor beta & P50395 & 51 & 2 & 7 \\
\hline $70^{b}$ & ras-related protein Rab-18 & Q9NP72 & 23 & 3 & 18 \\
\hline $71^{b}$ & rho-related GTP-binding protein RhoC & P08134 & 22 & 2 & 14 \\
\hline 72 & serum albumin & P02768 & 69 & 10 & 21 \\
\hline 73 & sulfhydryl oxidase 1 & O00391 & 83 & 2 & 3.7 \\
\hline $74^{b}$ & syndecan-4 & P31431 & 22 & 2 & 9.1 \\
\hline 75 & tenascin & $\mathrm{P} 24821$ & 241 & 58 & 36 \\
\hline 76 & thrombospondin-1 & P07996 & 129 & 3 & 4.5 \\
\hline 77 & triosephosphate isomerase & P60174 & 27 & 3 & 19 \\
\hline 78 & UTP-glucose-1-phosphate uridylyltransferase & Q16851 & 57 & 3 & 9.3 \\
\hline 79 & vitronectin & P04004 & 54 & 2 & 6.3 \\
\hline 80 & xanthine dehydrogenase/oxidase & P47989 & 146 & 39 & 41 \\
\hline 81 & zinc-alpha-2-glycoprotein & P25311 & 34 & 3 & 20 \\
\hline $82^{b}$ & zymogen granule protein 16 homologue B & Q96DA0 & 23 & 2 & 12 \\
\hline
\end{tabular}

${ }^{a}$ Accession numbers were assigned according to UniProt database Release 15.14. The complete identification statistics can be found in the Scaffold located in the proteome data set uploaded to the Tranche proteome commons repository. Serial number of proteins not previously detected in human milk whey are in bold. ${ }^{b}$ Proteins not found in the whey counterpart.

\section{RESULTS AND DISCUSSION}

In this study, data from milk casein collected at different time points of lactation were pooled and compared with a previous study, in which we analyzed the whey ${ }^{24}$ and milk fat globule membrane ${ }^{25}$ counterparts of the same samples. In the casein fractions of this study, 82 proteins with molecular weights ranging from 11 to $273 \mathrm{kDa}$ were identified (Table 1). Eighteen of these proteins were not present in their whey counterpart and 32 of them have previously not been identified in human milk or colostrum.

This study was a first attempt to examine whether there are soluble proteins associated with the casein micelle prepared by an acid-induced casein precipitation method, which is widely used for casein isolation. The data clearly indicated that other than caseins, there are specific minor proteins trapped in the micelle, which could be due to the following reasons: (1) Casein micelles are highly hydrated spheres, ${ }^{26}$ with approximately $4 \mathrm{~g}$ of water/g of total protein. ${ }^{27}$ Water within the casein micelle not only explains the considerable conformational flexibility, but also serves as a medium for soluble proteins; however, it is unlikely that the proteins identified were only "trapped", as they were not found in the whey fraction, suggesting specific association to the casein micelle. (2) Upon acid treatment, casein micelles start to aggregate when the $\mathrm{pH}$ goes below the isoelectric point of around $4.9,{ }^{28}$ but this also introduces formation of whey protein aggregates or whey gelation with the casein micelles, resulting in "whey protein-coated casein micelles", similar to the situation of other denaturation procedures, such as heat treatment or changing the salt content (ionic strength) of the aqueous phase. ${ }^{29-31}$ It is unlikely, however, that these whey aggregates would be so specific that there are no remainders in the whey fraction. Thus, it is likely that the unique whey proteins instead are specific components of the casein micelle and are associated with casein subunits during synthesis/excretion of milk by the mammary gland.

Therefore, the casein should rather be called the "casein fraction" or "casein complex", taking into account soluble proteins associated with casein. It should be noted that structural transitions constantly occur in the milk casein fraction, ${ }^{4}$ and the structure of the casein micelle results directly from interactions with nonmicellized components of the milk; results from this study may possibly represent this interaction. It is difficult to determine what the true "physiological" proteome of the casein micelle is, partly because the micelles range over a fairly wide 


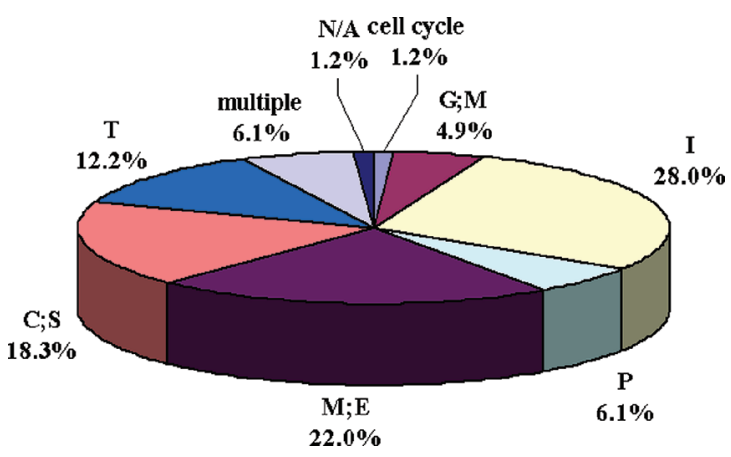

Figure 1. Pie graph representation of functional characterization of unique proteins identified in human milk casein. Numbers indicate the percentage share of each category. The abbreviations used are C;S (cell communication/signal transduction); I (immune response); G;M (cell growth and/or maintenance); T (transport); P (protein metabolism); $\mathrm{M} ; \mathrm{E}$ (metabolism/energy pathways); N/A (unknown).

range of size distribution and are difficult to isolate in "native" form without changing equilibria, even with differential centrifugation techniques. Thus, we resorted to the "classical" casein micelle isolation procedure, using acid, but optimized the conditions to avoid coprecipitation of other proteins.

Human milk casein mainly consists of $\beta$-casein and $\kappa$-casein, and in contrast to bovine milk, $\alpha$-caseins are usually considered absent or present in very low concentrations in human milk. ${ }^{32,33}$ We found $\beta$-casein, $\kappa$-casein, and $\alpha_{\mathrm{S} 1}$-casein, but not $\alpha_{\mathrm{S} 2 \text {-casein. }}$ Thus, $\alpha_{\mathrm{S} 2}$-casein could be considered to be absent from human milk. Biological functions have been suggested for bovine $\alpha$-caseins, but it is uncertain whether the human form will have any activity at this low concentration.

The protein profile was further explored by grouping the proteins into nine categories according to their functions (Figure 1). Compared to the casein fractions' whey counterpart, no proteins that function in nucleobase, nucleoside, nucleotide, and nucleic acid regulation were detected, and percentages of proteins involved in transport, cell communication/signal transduction, protein metabolism, and growth/maintenance are similar. Proteins involved in metabolism/energy production were lower in casein by $5.5 \%$ (22.0 in whey vs $16.5 \%$ in casein), and although proteins involved in immune function are somewhat lower in casein (34.8 in whey vs $28.0 \%$ in casein), immunity regulation is still the major functional group in casein, among which Golgi-associated plant pathogenesis-related protein 1 (PR-1) has not previously been identified. Tissue screening has revealed that high expression of PR-1 is found in monocytes, leukocytes, lung, spleen, and embryonic tissue, and the protein localizes to lipid-enriched microdomains in the Golgi complex. ${ }^{34}$ Interestingly, while proteins involved in cell communication/ signal transduction comprise $18.3 \%$ of the total proteins, $40 \%$ of them are located at the plasma membrane, including lactadherin, macrophage mannose receptor 1 , mucin 1 , mucin 4, Rho-related GTP-binding protein RhoC, and syndecan-4 (Table S1, Supporting Information). The major function of caseins is general transport, and aside from caseins, four new proteins were detected with general transport functions: platelet glycoprotein 4 (CD36) is suggested to transport long-chain fatty acids across the cell membrane and regulates cellular fatty acid uptake; ${ }^{35}$ chloride intracellular channel protein 1 is a chloride ion permeable protein transiently expressed in the cell membrane in

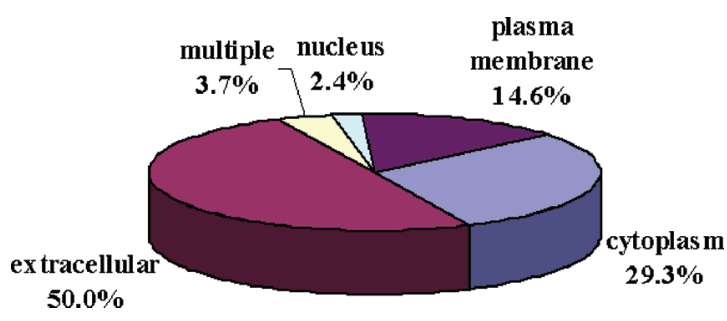

Figure 2. Pie graph representation of cellular localization distribution of unique proteins identified in human milk casein. Numbers indicate the percentage share of each category. N/A (unknown).

response to certain stimuli, e.g., oxidative stress; ${ }^{36}$ ATP-binding cassette subfamily $\mathrm{G}$ member 2 , isoform 1 , functions in the efflux of xenobiotic compounds and exhibits broad substrate specificity; ${ }^{37-39}$ and Ras-related protein Rab-18 is strongly suggested to be involved in ER-Golgi trafficking. ${ }^{40}$ It is possible that some of these proteins exert bioactivities in the breast-fed infant; however, it is likely that some of them reflect metabolic activities in the mammary gland occurring during milk biosynthesis.

The soluble proteins identified from milk casein were also divided into five groups based on their subcellular localization (Figure 2). Similar to what we have previously observed in the aqueous whey fraction, extracellular proteins are the predominant components of the casein fraction, in which they comprise $50.0 \%$ of total proteins. Cytoplasmic proteins (29.3\%) and plasma membrane proteins $(14.6 \%)$ were proportionally higher than in their whey counterpart (data not shown). It should be noted that there was one nucleus protein reported in this study, chloride intracellular channel protein 1 , which is a chloride ion permeable protein transiently expressed in the cell membrane in response to certain stimuli, e.g., oxidative stress. ${ }^{36}$

In summary, this study is the first to examine the composition of minor proteins in the human milk casein fraction prepared by an acid precipitation method. Results obtained showed that the functions of casein minor proteins span a broad spectrum, which may help to provide a better understanding of the physiological functions of the human milk casein fraction and may also provide suggestions for improved infant formulas by using selected fractions of bovine milk proteins. Some bovine milk proteins (e.g., lactoferrin and TGF- $\beta$ ) have been shown to exert bioactivities similar to those of their human milk counterparts and may therefore be considered for addition to infant formula. A better understanding of the human casein fraction and the biological activities of its constituents may help, as both specific protein constituents from bovine milk as well as different casein fractions prepared by methods such as acid precipitation or rennet treatment are commercially available.

\section{ASSOCIATED CONTENT}

\section{S Supporting Information}

Table S1: Names, functions, and locations of proteins identified in human milk casein fraction. This material is available free of charge via the Internet at http://pubs.acs.org.

\section{AUTHOR INFORMATION}

Corresponding Author

*Tel.: + 1 530-752-8347. Fax: +1 530-752-3564. E-mail: bllonnerdal@ ucdavis.edu. 


\section{Present Addresses}

RNA Biology Laboratory, Department of Genome Biology, The John Curtin School of Medical Research, College of Medicine, Biology, and Environment, Australian National University, ACT, Australia.

${ }^{\S}$ Molecular Instrumentation Center - Proteomics, Department of Chemistry and Biochemistry, University of California, Los Angeles, California 90095, United States.

\section{ACKNOWLEDGMENT}

We would like to thank Dr. Deshanie Rai for constructive discussions and Mead Johnson Nutrition for supporting this study. We also want to thank Dr. Ian J. Griffin for milk sample collections, Mrs. Xiaogu Du for milk casein micelle extraction, and Diana Tran and Bonnie Ching for LC-MS/MS sample preparations.

\section{REFERENCES}

(1) Lönnerdal, B. Nutritional and physiologic significance of human milk proteins. Am. J. Clin. Nutr. 2003, 77 (6), 1537S-1543S.

(2) Lönnerdal, B. Breast milk: A truly functional food. Nutrition 2000, 16 (7-8), 509-11.

(3) Lönnerdal, B. Bioactive proteins in human milk: Mechanisms of action. J. Pediatr. 2010, 156 (2 Suppl), S26-30.

(4) McMahon, D. J.; Oommen, B. S. Supramolecular structure of the casein micelle. J. Dairy Sci. 2008, 91 (5), 1709-21.

(5) Kunz, C.; Lönnerdal, B. Human-milk proteins: Analysis of casein and casein subunits by anion-exchange chromatography, gel electrophoresis, and specific staining methods. Am. J. Clin. Nutr. 1990, 51 (1), 37-46.

(6) Farrell, H. M., Jr.; Jimenez-Flores, R.; Bleck, G. T.; Brown, E. M.; Butler, J. E.; Creamer, L. K.; Hicks, C. L.; Hollar, C. M.; Ng-Kwai-Hang, K. F.; Swaisgood, H. E. Nomenclature of the proteins of cows' milksixth revision. J. Dairy Sci. 2004, 87 (6), 1641-74.

(7) Vincenzetti, S.; Polidori, P.; Mariani, P.; Vita, A. Protein fraction characterization of sheep milk from the Comisana breed. Vet. Res. Commun. 2008, 32 (Suppl 1), S179-81.

(8) Sato, R.; Noguchi, T.; Naito, H. Casein phosphopeptide (CPP) enhances calcium absorption from the ligated segment of rat small intestine. J. Nutr. Sci. Vitaminol. 1986, 32 (1), 67-76.

(9) Tsuchita, H.; Suzuki, T.; Kuwata, T. The effect of casein phosphopeptides on calcium absorption from calcium-fortified milk in growing rats. Br. J. Nutr. 2001, 85 (1), 5-10.

(10) Datta, S.; Patterson, E. H.; Vincitore, M.; Tonkiss, J.; Morgane, P. J.; Galler, J. R. Prenatal protein malnourished rats show changes in sleep/wake behavior as adults. J. Sleep Res. 2000, 9 (1), 71-9.

(11) Stromqvist, M.; Falk, P.; Bergstrom, S.; Hansson, L.; Lönnerdal, B.; Normark, S.; Hernell, O. Human milk kappa-casein and inhibition of Helicobacter pylori adhesion to human gastric mucosa. J. Pediatr. Gastroenterol. Nutr. 1995, 21 (3), 288-96.

(12) Li, E. W.; Mine, Y. Immunoenhancing effects of bovine glycomacropeptide and its derivatives on the proliferative response and phagocytic activities of human macrophagelike cells, U937. J. Agric. Food Chem. 2004, 52 (9), 2704-8.

(13) Hoppe, C.; Molgaard, C.; Dalum, C.; Vaag, A.; Michaelsen, K. F. Differential effects of casein versus whey on fasting plasma levels of insulin, IGF-1 and IGF-1/IGFBP-3: Results from a randomized 7-day supplementation study in prepubertal boys. Eur. J. Clin. Nutr. 2009, 63 (9), 1076-83.

(14) Saito, T. Antihypertensive peptides derived from bovine casein and whey proteins. Adv. Exp. Med. Biol. 2008, 606, 295-317.

(15) Jiang, J.; Chen, S.; Ren, F.; Luo, Z.; Zeng, S. S. Yak milk casein as a functional ingredient: Preparation and identification of angiotensin-Iconverting enzyme inhibitory peptides. J. Dairy Res. 2007, 74 (1), 18-25.
(16) Cadee, J. A.; Chang, C. Y.; Chen, C. W.; Huang, C. N.; Chen, S. L.; Wang, C. K. Bovine casein hydrolysate (c12 Peptide) reduces blood pressure in prehypertensive subjects. Am. J. Hypertens. 2007, 20 (1), 1-5.

(17) Silanikove, N.; Shapiro, F.; Shamay, A.; Leitner, G. Role of xanthine oxidase, lactoperoxidase, and NO in the innate immune system of mammary secretion during active involution in dairy cows: Manipulation with casein hydrolyzates. Free Radicals Biol. Med. 2005, 38 (9), 1139-51.

(18) Alexander, M.; Dalgleish, D. G. Interactions between denatured milk serum proteins and casein micelles studied by diffusing wave spectroscopy. Langmuir 2005, 21 (24), 11380-6.

(19) Ferlin, M. L.; Santoro, J. R.; Jorge, S. M.; Goncalves, A. L. Total nitrogen and electrolyte levels in colostrum and transition human milk. J. Perinat. Med. 1986, 14 (4), 251-7.

(20) Kunz, C.; Lönnerdal, B. Human milk proteins: Separation of whey proteins and their analysis by polyacrylamide gel electrophoresis, fast protein liquid chromatography (FPLC) gel filtration, and anionexchange chromatography. Am. J. Clin. Nutr. 1989, 49 (3), 464-70.

(21) Keller, A.; Nesvizhskii, A. I.; Kolker, E.; Aebersold, R. Empirical statistical model to estimate the accuracy of peptide identifications made by MS/MS and database search. Anal. Chem. 2002, 74 (20), 5383-92.

(22) Nesvizhskii, A. I.; Keller, A.; Kolker, E.; Aebersold, R. A statistical model for identifying proteins by tandem mass spectrometry. Anal. Chem. 2003, 75 (17), 4646-58.

(23) Tabb, D. What's driving false discovery rates? J. Proteome Res. 2008, 7 (1), 45-6.

(24) Liao, Y.; Alvarado, R.; Phinney, B.; Lönnerdal, B. Proteomic characterization of human milk whey proteins during a twelve-month lactation period. J. Proteome Res. 2011, 10 (4), 1746-54.

(25) Liao, Y.; Alvarado, R.; Phinney, B.; Lönnerdal, B. Proteomic characterization of human milk fat globule membrane proteins during a 12 month lactation period. J Proteome Res. 2011, 10 (8), 3530-41.

(26) Dewan, R. K.; Chudgar, A.; Mead, R.; Bloomfield, V. A.; Morr, C. V. Molecular weight and size distribution of bovine milk casein micelles. Biochim. Biophys. Acta 1974, 342 (2), 313-21.

(27) De Kruif, C. G.; Holt, C. Casein micelle structure, functions, and interactions. Advanced Dairy Chemistry-1. Proteins. Part A; Kluwer Academic/Plenum Publishers: New York, 2003.

(28) Heertje, I.; Visser, J.; Smits., P. Structure formation in acid milk gels. Food Microstruct. 1985, 4, 266-7.

(29) Singh, H.; Roberts, M. S.; Munro, P. A.; Teo, C.; Tet Acidinduced dissociation of casein micelles in milk: Effects of heat treatment. J. Dairy Sci. 1996, 79, 1340-6.

(30) Vasbinder, A. J.; van de Velde, F.; de Kruif, C. G. Gelation of casein-whey protein mixtures. J. Dairy Sci. 2004, 87 (5), 1167-76.

(31) Hernandez, A.; Harte, F. M. Isolation of caseins from whey proteins by microfiltration modifying the mineral balance in skim milk. J. Dairy Sci. 2009, 92 (11), 5357-62.

(32) Greenberg, R.; Groves, M. L.; Dower, H. J. Human beta-casein. Amino acid sequence and identification of phosphorylation sites. J. Biol. Chem. 1984, 259 (8), 5132-8.

(33) Chobert, J. M.; Mercier, J. C.; Bahy, C.; Haze, G. Primary structure of the casein macropeptide of porcine and human kappa caseins. FEBS Lett. 1976, 72 (1), 173-8.

(34) Eberle, H.; Serrano, R.; Füllekrug, J.; Schlosser, A.; Lehmann, W.; Lottspeich, F.; Kaloyanova, D.; Wieland, F.; Helms, J. Identification and characterization of a novel human plant pathogenesis-related protein that localizes to lipid-enriched microdomains in the Golgi complex. J. Cell Sci. 2002, 115 (Pt 4), 827-38.

(35) Schwenk, R.; Holloway, G.; Luiken, J.; Bonen, A.; Glatz, J. Fatty acid transport across the cell membrane: Regulation by fatty acid transporters. Prostaglandins, Leukotrienes Essent. Fatty Acids 2010, 82 (4-6), 149-54.

(36) Averaimo, S.; Milton, R. H.; Duchen, M. R.; Mazzanti, M. Chloride intracellular channel 1 (CLIC1): Sensor and effector during oxidative stress. FEBS Lett. 2010, 584 (10), 2076-84.

(37) Adachi, Y.; Suzuki, H.; Schinkel, A. H.; Sugiyama, Y. Role of breast cancer resistance protein $(\mathrm{Bcrp} 1 / \mathrm{Abcg} 2)$ in the extrusion of 
glucuronide and sulfate conjugates from enterocytes to intestinal lumen. Mol. Pharmacol. 2005, 67 (3), 923-8.

(38) Breedveld, P.; Zelcer, N.; Pluim, D.; Sonmezer, O.; Tibben, M. M.; Beijnen, J. H.; Schinkel, A. H.; van Tellingen, O.; Borst, P.; Schellens, J. H. Mechanism of the pharmacokinetic interaction between methotrexate and benzimidazoles: Potential role for breast cancer resistance protein in clinical drug-drug interactions. Cancer Res. 2004, 64 (16), 5804-11.

(39) Hirano, M.; Maeda, K.; Matsushima, S.; Nozaki, Y.; Kusuhara, H.; Sugiyama, Y. Involvement of BCRP (ABCG2) in the biliary excretion of pitavastatin. Mol. Pharmacol. 2005, 68 (3), 800-7.

(40) Dejgaard, S.; Murshid, A.; Erman, A.; Kizilay, O.; Verbich, D.; Lodge, R.; Dejgaard, K.; Ly-Hartig, T. B.; Pepperkok, R.; Simpson, J.; Presley, J. Rab18 and Rab43 have key roles in ER-Golgi trafficking. J. Cell Sci. 2008, 121 (Pt 16), 2768-81. 